\title{
FACTORS ASSOCIATED TO INFLUENZA VACCINATION IN THE ELDERLY: AN INTEGRATIVE REVIEW
}

\author{
FATORES ASSOCIADOS À VACINAÇÃO CONTRA A INFLUENZA EM IDOSOS: \\ UMA REVISÃO INTEGRATIVA \\ Maria de Fátima da Silva Moreira, "* Maria Eduarda de Sousa Paulo, II Salmana Rianne Pereira Alves, III \\ Glaydes Nely Sousa da Silva IV
}

\begin{abstract}
It is known that several reasons for the non-adherence of the elderly population to influenza vaccination are discussed in the literature. The understanding about such factors supports the development of strategies to encourage the search for vaccination. Thus, the present study aims at analyzing the main factors associated with the non-adherence to influenza vaccination among the elderly. This is an integrative review, conducted in the LILACS, SCIELO and PUBMED databases, having as descriptors: elderly; influenza and vaccination. As inclusion criteria: original research articles published in the last 12 years (2008 to 2020). Regarding the associated factors contributing to the non-adherence to vaccination, demographic characteristics, lack of time to go to the healthcare unit, refusal of vaccination for several reasons, lack of knowledge, illness after other previous vaccinations, the lack of interest in taking it, overall disbelief in the vaccine and not having information about the vaccine stand out. Thus, campaigns and projects that aim at educationally informing the elderly about vaccination, must encompass these aspects and implement specific strategies to satisfactorily reach the target audience's adhesion to influenza vaccination.
\end{abstract}

KEYWORDS: Elderly. Influenza. Vaccination.

Resumo. Sabe-se que diversos motivos da não adesão dos idosos à vacinação contra influenza são discutidos na literatura. A compreensão acerca de tais fatores fundamenta o desenvolvimento de estratégias que estimulam a busca pela vacinação. Assim, o presente estudo tem o objetivo de analisar os principais fatores associados à vacinação contra a influenza que influenciam na não adesão dos idosos. Trata-se de uma revisão integrativa, realizada nas bases de dados LILACS, SCIELO e PUBMED. Tendo como descritores: idosos, influenza e vacinação. Como critérios de inclusão: artigos originais de pesquisa publicados nos últimos 12 anos (2008 a 2020). No que diz respeito aos fatores associados à vacinação que contribuem para não adesão, destacam-se as características demográficas, a falta de tempo de ir à unidade, a recusa da vacinação por motivos variados, a falta de conhecimento, o adoecimento após outra vacinação, a falta de interesse em tomar ou não, acreditar na vacina e não possuir a informação sobre a vacina. Assim, as campanhas e os projetos que visam informar de modo educativo os idosos a respeito da vacinação, devem compreender tais aspectos e implementar estratégias específicas para alcançar satisfatoriamente a adesão do público-alvo à vacinação contra influenza.

PALAVRAS-CHAVE: Idosos. Influenza. Vacinação.

'Enfermeira, Especialista em Saúde da Família. Faculdade de Enfermagem Nova Esperança FACENE. CEP: 58067-695, João Pessoa, Paraíba, Brasil. *Autor correspondente: fatimamoreiraenf@outlook.com. ORCID ID: 0000-0003-0213-8460.

"Iraduanda em Enfermagem. Faculdade de Enfermagem Nova Esperança FACENE. CEP: 58067-695, João Pessoa, Paraíba, Brasil. ORCID ID: 0000-0002-0725-2679.

IIIEnfermeira, Mestre Saúde da família. Faculdade de Enfermagem Nova Esperança FACENE. CEP: 58067-695, João Pessoa, Paraíba, Brasil. ORCID ID: 0000-0002-4472-2289.

IV Enfermeira, Mestre em Terapia intensiva e Saúde da família. Faculdade de Enfermagem Nova Esperança FACENE. CEP: 58067-695, João Pessoa, Paraíba, Brasil. ORCID ID: 0000-0002-6564-657X. 


\section{INTRODUCTION}

The increase in life expectancy worldwide is due to several factors and, for this reason, elderly health has gained notoriety in the general health care agenda. Primary Care is responsible for fostering active aging and comprehensive care for the elderly. Health policies have the attribution of strengthening the established actions in health care for the elderly, contributing to healthy aging, ${ }^{1}$ implementing strategies to reduce the burden of diseases in this population, including vaccination. ${ }^{2}$

One of the effects of aging is the increase in incidence and aggravation of infectious diseases. Influenza is a pathology that presents itself as an infectious and acute flu, caused by the Haemophilus influenzae virus, which it affects the respiratory system. In the elderly, infections can be more severe, due to lower immunity, generally enabling the emergence of pneumonia and the aggravation of preexisting illnesses, resulting in hospitalization. Influenza vaccination is essential to control the circulation of the virus worldwide. The virus mutates, which requires extensive global control and recurrent updating of the vaccine. Therefore, annual vaccination is required, and priority groups can receive it for free at health care units. ${ }^{3}$

The vaccination campaign is an important activity at the national level, in which priority groups are relevant social actors in the process of disease prevention and control. 60-year-old and older individuals should receive the influenza vaccine based on the influenza vaccination strategy that describes them as one of the priority groups. ${ }^{4}$ Influenza vaccination is the most effective way to prevent the severe form of the infection and hospitalizations. However, there is a persistent refusal by some elderly people to adhere to the campaigns. Despite the gratuitousness of annual vaccination campaigns in Brazil, the non-adherence of the elderly causes the underachievement of the goals established by the Ministry of Health. ${ }^{5}$

Several reasons for the nonadherence of elderly people to influenza vaccination are discussed in the literature, such as the fear of adverse reactions and the lack of credibility in the effectiveness of the vaccine. 6 Investigating the aspects that influence vaccination favors a beneficial discussion about the challenges that must be solved by the Family Health Strategy (ESF) to provide primary care in Brazil. ${ }^{7}$

Thus, understanding the factors associated with vaccination and the reasons for non-adherence by the elderly are relevant for health professionals to develop strategies to promote adequate knowledge on vaccination and its benefits, especially to the population whose access to overall health information as well as the vaccination campaigns of the Ministry of Health is restricted. In this sense, the importance of monitoring the vaccination status of the elderly and the study of associated factors are emphasized, which improve prevention strategies aiming to reduce the occurrence of health problems in the elderly, the complications from vaccine-preventable diseases, and hospitalization rates. 8

Immunization corresponds to a recommendation of the World Health Organization (WHO), which includes healthy individuals as well as those vulnerable to certain pathologies. However, vaccination in adults, especially in the elderly population, is a challenge to be faced in the current context. $^{9}$

Professionals must respect the world 
view of each elderly person, so that they can feel comfortable and encouraged to participate in campaigns over years to come. ${ }^{5}$ It is essential to adopt health care strategies in order to support immunization programs, making full vaccination coverage among the elderly population possible. Influenza vaccination campaigns should publicize and present the positive aspects of vaccination from the age of 60 onwards, discussing the indications and risks for this target audience

\section{METHODOLOGY}

The present study is an integrative literature review, carried out through six stages. The first stage corresponded to the delimitation of the research question; in the second stage, a search in the literature (sampling) was carried out; in the third, data was collected; the critical analysis of the included studies was carried out in the fourth stage; in the fifth stage, the results were discussed; and the sixth stage consisted of the presentation of the integrative review. ${ }^{11,12,13}$

Information compilation through electronic media is a great advance for researchers, democratizing access and providing frequent updates. This research was carried out from July to October 2020 in the Latin American and Caribbean Literature on Health Sciences (LILACS), Scientific Electronic Library Online (SCIELO) and PUBMED databases. The bibliographic research comprised the following terms as descriptors: elderly, influenza and vaccination. in order to encourage adherence to the National Immunization Program and favor the achievement of the established goals in all states and municipalities of the country. $7,10,6$

Based on the aforementioned, a question was raised: what are the main factors associated with influenza vaccination in the elderly and the reasons for non-adherence? Aiming to analyze the main factors associated with influenza vaccination that influence the non-adherence of the elderly.

As inclusion criteria, we specified original research articles based on the three selected descriptors published in the last 12 years (2008 to 2020), available in full, free of charge, in the online databases, in which the content corresponded to the main objective and research problem/question.

As exclusion criteria we determined that monographs, dissertations, book chapters and other materials that were not original articles with research data be excluded from the study. Articles involving other groups of individuals, such as newborns, children and adults, were also excluded. Furthermore, articles referring to another area of study, incomplete and marked as reviews were also excluded.

Regarding the data from this study, they were analyzed using a qualitative approach and presented through a conceptual map and tables and discussed according to the central thesis of the research.

\section{RESULTS}


three) were excluded according to the preestablished inclusion and exclusion criteria, resulting in 7 (seven) articles for analysis and development. The articles were excluded because they were not in accordance with the central theme of the research, discussed other vaccines, such as Hepatitis $B$, dealt with different target audiences, which resulted in distancing from the objectives and criteria established in this research.
The summary of the articles that make up the corpus of this research directly or indirectly show the factors associated with influenza vaccination in elderly populations. These articles are organized in Table 1 according to their titles, objectives and conclusions. Furthermore, the results suggest strategies that aim to promote the adherence of the elderly to influenza vaccination.

TABLE 1: Summary of the articles related to influenza vaccination in the elderly published from 2008 to 2020.

\begin{tabular}{|c|c|c|}
\hline Título do trabalho & Objective & Conclusion \\
\hline $\begin{array}{l}\text { Influenza vaccination among } \\
\text { elderly in Pelotas-RS, Brazil, } \\
2014: \text { a population-based } \\
\text { study }^{14}\end{array}$ & $\begin{array}{l}\text { To describe the prevalence of those } \\
\text { vaccinated against influenza and factors } \\
\text { associated with vaccination in the elderly; to } \\
\text { identify reasons for non-adherence and post- } \\
\text { vaccination adverse events. }\end{array}$ & $\begin{array}{l}\text { Vaccination coverage was not universal; } \\
\text { instructional approaches are needed to explain } \\
\text { controversies about the efficacy, adverse events, } \\
\text { and benefits of influenza vaccination. }\end{array}$ \\
\hline $\begin{array}{l}\text { Factors associated with ad- } \\
\text { herence to influenza vaccina- } \\
\text { tion among non-institution- } \\
\text { alized elderly in São Paulo, } \\
\text { Brazil }^{10}\end{array}$ & $\begin{array}{l}\text { To estimate influenza vaccine coverage in the } \\
\text { elderly and identify factors associated with } \\
\text { adherence to vaccination. }\end{array}$ & $\begin{array}{l}\text { Vaccination coverage was not universal; } \\
\text { instructional approaches are needed to explain } \\
\text { controversies about the efficacy, adverse events, } \\
\text { and benefits of influenza vaccination. It was found } \\
\text { to be necessary to encourage the vaccination of } \\
\text { elderly people under } 70 \text { years of age and those } \\
\text { without chronic diseases, as well as to guide health } \\
\text { professionals to expand coverage in groups with } \\
\text { less participation in the campaigns. }\end{array}$ \\
\hline
\end{tabular}

Vaccination against influenza To analyze the prevalence of influenza in the elderly: data from vaccination in the elderly, according to FIBRA, Campinas, São Paulo, indicators of functional capacity, frailty, Brazil $^{19} \quad$ support and social engagement, and health status.

Factors associated with To analyze the prevalence of influenza influenza vaccination among vaccination in the elderly, according to the elderly: a cross-sectional indicators of functional capacity, frailty, study in Cambé, Paraná State, support and social engagement, and health Brazil status. To estimate the influenza vaccine coverage in elderly people living in the areas covered by the Family Health Strategy in the municipality of Cambé, Paraná State.

Influenza vaccination among To evaluate the prevalence of influenza elders: prevalence, associated vaccination in the elderly and identify the factors, and reasons for associated factors and reasons for nonnoncompliance in Campinas, adherence to immunization. São Paulo State, Brazil $^{17}$
The vaccination prevalence was significantly higher among men and lower among more educated people.

They suggest the need for health care strategies, considering the factors that interfere with voluntary adherence to vaccination, contributing to increasing the chances of successful immunization.

They suggest the need for health care strategies, considering the factors that interfere with voluntary adherence to vaccination, contributing to increasing the chances of successful immunization. The main reasons for non-adherence were: not considering it necessary and the belief that it causes undesirable reactions. Socioeconomic conditions, lifestyle and physical mobility did not restrict access, but coverage was below the Ministry of Health goal.

Influenza vaccination for the To describe the profile of the elderly and elderly at a teaching health assess information they have about influenza care unit in São Paulo, Brazil ${ }^{18}$
The elderly had information about vaccination, but there is still a need for nurses and other professionals in the area to take responsibility for more precise guidance on the importance of vaccination against influenza and its complications.

The factors associated with vaccination presented a multidimensional structure, which included demographic characteristics, healthy habits and use of health services. 


\section{DISCUSSION}

Educational campaigns are important to inform the elderly about the effectiveness and benefits of influenza vaccination. ${ }^{14}$ In the same perspective, there is a need to implement health care strategies, aiming to increase the positive results of vaccination campaigns. ${ }^{7}$ For this reason, it is evident the need to encourage the vaccination of elderly people under 70 and without chronic diseases. ${ }^{10}$

As for the benefits, the advantages of vaccination include improved quality of life, reduced spending on medication, reduced hospitalizations and deaths. ${ }^{15}$ Influenza vaccination campaigns should be publicized, in order to raise awareness to the advantages of getting vaccinated. Information about indications and risks, targeting the younger age group (60-69 years old) and aimed mainly at low-income elderly and those with chronic diseases (cardiovascular, pulmonary and metabolic) to increase vaccination coverage in these specific groups that have showed low adherence to campaigns in previous research. ${ }^{7}$ It is noteworthy that those with chronic diseases and who are more predisposed to complications, had a lower degree of vaccination coverage. ${ }^{16}$

It is extremely important for the advancement of public health to prevent the spread of these diseases. Elderly people, especially the institutionalized ones, are highly benefited, since vaccines provide high protection against possible pathological complications. ${ }^{15}$ Economic status, lifestyle and physical mobility did not hinder access to vaccination, contributing to the expansion of the campaign. However, vaccination coverage in the elderly population residing in Campinas was considered below the target established by the Ministry of Health.
Therefore, campaigns focusing on the elderly should receive attention, as well as the guidance of health professionals. ${ }^{17}$

The influenza vaccine has not yet reached the elderly universally. Socioeconomic inequalities, specific characteristics in the use of health services and behavioral factors are the main issues that prevent adherence to vaccination. In this context, health professionals have a fundamental role in the recommendation of the vaccine, alleviating possible misunderstandings and educating on the controversial issues about the effectiveness of the vaccine and adverse events that may happen in the elderly due to vaccination. ${ }^{14}$

The influenza vaccination coverage among elderly residents in the Metropolitan Region of Belo Horizonte was below the $90 \%$ goal recommended by the health indicator 2010 Healthy People, proposed by the U.S Department of Health and Human Services, but was close to the $70 \%$ target established by the Ministry of Health. ${ }^{16}$ The elderly in the survey showed that they obtained information on vaccination, however, there was still a need for health professionals, such as nurses and other professionals, to be responsible for a clearer guidance on the relevance of vaccination against influenza and existing complications. ${ }^{18}$

Different aspects can be observed regarding the issue of vaccination coverage and the factors associated with the influenza vaccination, since each Brazilian region has distinct characteristics, as well as selected audiences and, thus, the results can be diversified. This means that the following actions of the government and health professionals must be guided by these individuals' respective realities, envisioning 
specific strategies to improve vaccination coverage in the elderly.

In order to better understand the aspects related to vaccination, table 2 presents the main factors associated with influenza vaccination in elderly Brazilians based on the research results.

TABLE 2: Main factors associated with influenza vaccination in elderly.

\begin{tabular}{|c|c|}
\hline Author/Year & Main factors associated to influenza vaccination in elderly \\
\hline $\begin{array}{l}\text { Neves, Duro \& Tomasi } \\
(2016)^{14}\end{array}$ & $\begin{array}{l}\text { Economic status was considered determinant to vaccine adherence. Elderly people with better economic } \\
\text { positions }(A \text { and } B) \text { had higher influenza vaccination numbers. Socioeconomic inequalities, health service } \\
\text { use characteristics and behavioral factors are determinant for adherence to vaccination. }\end{array}$ \\
\hline $\begin{array}{l}\text { Moura, Andrade, } \\
\text { Duarte, Lebrão, } \\
\text { Antunes (2015) }\end{array}$ & $\begin{array}{l}\text { Influenza vaccination was associated with older age, with the presence of chronic diseases and with use } \\
\text { of health care services in the previous year. The understanding that the vaccine would not be effective } \\
\text { or really important was mentioned as the most prominent reason for non-adherence by the interviewed } \\
\text { individuals. However, the lack of association between adherence and socioeconomic variables showed } \\
\text { that influenza vaccination is nor affected by inequalities in the city of São Paulo. }\end{array}$ \\
\hline $\begin{array}{l}\text { Francisco, Borim \& Neri } \\
(2015)^{19}\end{array}$ & $\begin{array}{l}\text { Vaccination was considerably higher among men and lower among more educated people. Slow walking } \\
\text { pace was positively associated with vaccination, as were most indicators of social involvement. }\end{array}$ \\
\hline $\begin{array}{l}\text { Campos, Sudan, } \\
\text { Mattos, Fidelis } \\
(2012)^{7}\end{array}$ & $\begin{array}{l}\text { Age was considered a factor associated with influenza vaccination. Greater adherence of older elderly } \\
\text { people, over } 70 \text { years old. Income was also associated, in which the elderly who reported higher income } \\
\text { adhered more to vaccination. Furthermore, hypertensive elderly people were reported as having higher } \\
\text { vaccination rates, as well as elderly people who regularly exercised. }\end{array}$ \\
\hline $\begin{array}{l}\text { Francisco, Barros \& } \\
\text { Cordeiro (2011) }\end{array}$ & $\begin{array}{l}\text { Greater guidance on vaccination was observed among the elderly who did not perform an occupational } \\
\text { activity. A higher prevalence was also found among the elderly who considered their health to be good at } \\
\text { the time of the survey. }\end{array}$ \\
\hline $\begin{array}{l}\text { Geronutti, Molina \& Lima } \\
(2008)^{18}\end{array}$ & $\begin{array}{l}\text { It was found that the elderly obtained information about vaccination through radio and television, and } \\
\text { declared that its importance is related to prevention. }\end{array}$ \\
\hline Lima-Costa $(2008)^{16}$ & $\begin{array}{l}\text { Results showed that the coverage of vaccination in the studied population was close to the target of } \\
70 \% \text { determined by the Ministry of Health. The factors associated with vaccination demonstrated a } \\
\text { multidimensional structure, which included demographic characteristics, healthy habits and use of health } \\
\text { services. }\end{array}$ \\
\hline
\end{tabular}

Source: Research data (2020).

Vaccination coverage among elderly people in the municipality of Cambé between 2008 and 2009 did not reach the goal of $80 \%$, as determined by the Ministry of Health. Age, income, regular physical activity and elderly hypertensive individuals were investigated as factors associated with vaccination. However, no association of vaccination with health and lifestyle variables was found, such as oneself health perception, hospitalization in the previous year, smoking and associated comorbidities, which suggested an absence of epidemiological criteria leading the actions in health. ${ }^{7}$

No relevant associations were found between influenza vaccination and healthrelated behaviors, except for the regular practice of physical activity for leisure purposes, which was observed independently from immunization. The study also highlighted that socioeconomic conditions, lifestyle and physical mobility did not restrict access to vaccination in the municipality, demonstrating the scope of the campaigns. ${ }^{17}$

Socioeconomic issues are one of the aspects that should receive attention from health professionals and the government when it comes to aspects related to influenza vaccination in elderly people, as low financial resources can be a trigger point for the individual to be unable to obtain the access to adequate information about what vaccination actually is, the reasons for the it for the health as well as grasping the knowledge about aspects related to vaccination. Despite not having achieved the vaccination goal determined by the Ministry of Health, the data highlighted the scope of vaccination campaigns in Campinas, in 2008, both among elderly people with less physical mobility, as well as those highly functioning elders. Also, the prevalence of vaccination among the 
elderly who demonstrated a slow walking pace was considerably higher. Furthermore, no statistically relevant differences were found between the rate of elderly people vaccinated in association with self-reported diseases, such as diabetes, cardiovascular disease, stroke/ischemia or lung disease. ${ }^{19}$

Two years prior, in 2006, in the city of São Paulo, the proportion of vaccinated elderly corresponded to $73.8 \%$, which was considered to be compatible with the estimate determined by the municipality Health Department, which reported that $79 \%$ of people aged 60 years or older living in the city were vaccinated that year. In that research, there was an effect between vaccination and chronic diseases, since one of the reasons that explains this rate is related to the fact that high blood pressure and diabetes are conditions of significant prevalence in the elderly and, probably, these individuals go more frequently to health service facilities to collect medication and receive appropriate treatment. ${ }^{10}$

The primary goal of the strategy in this population is the adherence to vaccination, since the elderly are more susceptible to diseases because they have weaker immune system.20 The elderly who mentioned having habits that are harmful to their health or prone to illnesses arising from the flu did not have greater vaccine coverage in the research, demonstrating the need to receive more information about the vaccine's advantages in these certain contexts. ${ }^{16}$

In order to receive information about their comorbidities, other important health issues were presented to the elderly, such as vaccination campaigns. Therefore, the information and guidance presented by health professionals are fundamental with regard to immunization. ${ }^{10}$ Most elderly people received adequate information about the importance of vaccination to ensure prevention, whether through radio or television. Thus, it is essential to highlight the importance of maintaining the campaign strategies that are implemented in Brazil. ${ }^{18}$

In this sense, information is the key element to increase adherence to vaccination among the elderly, since the lack of information about vaccines and campaigns is one of the reasons that prevent the elderly from being vaccinated. Many of these elderly people have low education level, and therefore need to receive proper guidance. Health professionals, especially nurses, are closer to patients and have as one of their duties to welcome these individuals and explain some information about vaccination, guiding and dispelling myths and prejudices regarding the vaccine, in order to elevate the number of elderly consenting parties. 5,9

The importance and need for health care strategies are highlighted in this context, corroborating the factors that interfere with voluntary adherence to vaccination of the elderly, so that satisfactory results are met with regard to immunization programs. In order to reach full vaccination coverage for these individuals, campaigns must promote and explain their respective benefits. ${ }^{7}$

The broadcast of vaccination campaigns through mass media agencies allow for greater dissemination and awareness of the need for vaccination against the influenza virus. A refusal for the vaccination on the part of the elderly can be related to the fear that it might be harmful to their health, since this is still a reason that prevents vaccination from a considerable part of the target population that should get the vaccine. Thus, it is necessary to use the media to raise awareness to the greatest number of elderly people. The Brazilian federal government must incorporate in the financial planning of the Influenza vaccination campaign an amount to be destined to its publicity campaign. ${ }^{3}$

Thus, information and guidance by health professionals to the elderly regarding the elucidation of the influenza vaccine will 
contribute to alleviate the insecurity and fear of reactions due to side effects that these elderly people have. ${ }^{21,3}$ In this perspective, the technical information should be available at all vaccination sites, disseminated to the scientific community and society as a whole. ${ }^{3}$ Unsatisfactory knowledge was found regarding the purpose and relevance of vaccination strategies and public policies implemented by the Ministry of Health. Some reasons for not being vaccinated stood out, among them the lack of time to get to the health care unit, the refusal to the vaccination, the lack of knowledge, illness after another previous vaccination, the lack of interest in taking or not believing in the vaccine and not having information about the vaccine. ${ }^{22}$ Thus, the guidance by health professionals is essential when it comes to informing these individuals and expanding influenza immunization programs. It is important to highlight the need for a broader participation by the Family Health Strategy (FHS) teams in homes and other environments, such as community centers, neighborhood activities and churches. ${ }^{7}$

Nursing professionals must be aware that it is essential to implement health strategies in order to favor the success of immunization programs, aiming to ensure full vaccination coverage for the elderly population. In this perspective, vaccination campaigns should better publicize and guide the advantages of vaccination from the age of 60 onwards, giving information about the indications and risks, especially for lowincome elderly people and those with chronic diseases, to expand the vaccination coverage in these specific groups. ${ }^{9}$

The lack of professional training may lead to disruptions in the immunization process, especially with regards to the strengthening of beliefs and myths about vaccines, which results in the non-adherence by the elderly population. ${ }^{23}$ Thus, in order to avoid awareness deficit about the importance of vaccination in preventing certain diseases, its adverse reactions and how to proceed in the event of such reactions, it is essential that the professionals responsible for the administration have received prior training, which enables them to establish effective communication with the patient. ${ }^{15}$

In order to develop strategies aimed at increasing vaccination coverage, several dimensions must be taken into account regarding the factors associated with vaccination, such as demographic characteristics (age and marital status), healthy habits (regular exercise practice) and use of health services (blood pressure measurement and recent medical consultations). ${ }^{16}$ Thus, understanding the aspects related to coverage and determining the factors associated with influenza vaccination in the elderly is relevant to the literature, because by knowing the reality of these individuals and the main reasons that make this public choose not to be vaccinated, allow health professionals and the government to implement actions aimed at reversing this context, offering the necessary information about the benefits of this practice.

\section{FINAL REMARKS}

Adherence strategies to vaccination are beneficial for the elderly and should be encouraged in order to reach the goals established by each municipality Health Department. Vaccination campaigns are intended to reduce complications, 
hospitalizations and mortality resulting from influenza virus infections. The concern with understanding the factors associated with vaccination is justified based on the aim of implementing actions to reach a broader number of the target audience.

As for the factors associated with vaccination, we can highlight, for example, economic inequalities, particularities in the use of health services, behavioral factors, demographic characteristics, healthy habits, hypertension, diabetes, elderly people who do not perform an occupational activity. Regarding the aspect of demographic characteristics, we mentioned age, for example, which can be considered an associated factor, as the older the age, the greater the adherence. Furthermore, income is also associated, as the higher the income, the greater the adherence to vaccination.

Some reasons for non-vaccination were mentioned in this research, including the lack of time to go to the healthcare site, the refusal of vaccination for several reasons, the lack of knowledge, illnesses after another previous vaccination, the lack of interest in taking it or not, the belief in it and not having

\section{REFERENCES}

1. Luz A, Niering DB, Silva SL. Caderneta de Saúde da Pessoa Idosa: conscientização dos profissionais nas Unidades Básicas de Saúde no município de Joinville. 2018. Available at: <http://joinville. ifsc.edu.br/ bibliotecajoi/arquivos/monografias/ saudeidoso2018/197406.pdf> Access on: Aug. 03rd 2020.

2. Reis SAA. A importância da vacinação no idoso. 2015. Available at: < https://core.ac.uk/download/ pdf/43589553.pdf $>$ Access on: Oct. 20th 2020.

3. Santos RR, Côrrea MA. Determinantes que dificultam a adesão da vacina antigripal por idosos. information about the vaccine.

In addition to the factors mentioned, campaigns and projects that aim to educationally inform the elderly about vaccination must understand the respective distinct aspects that may involve this process, such as the issue of prejudice, insecurity and lack of information of these people. Thus, strategies must be implemented taking these aspects into account, to satisfactorily reach the target audience. Governments must implement actions taking into account the factors associated with vaccination and the specificities of each region, so that these individuals are offered proper knowledge and adequate information.

Knowing the importance that health professionals have in the influenza vaccination process, as a suggestion for further research, we recommend the development of studies with these professionals, especially nursing professionals, so that the factors associated with vaccination and mainly the reasons that make the elderly not adhere to this practice based on the perspective of these professionals is better understood.

2015. Available at: < http://www.ipec-pa.com.br/ aluno/arquivos/tcc/correa_santos.pdf> Access on: Aug. 22nd 2020.

4. Brasil. Informe Técnico. $22^{\mathrm{a}}$ Campanha Nacional de Vacinação contra a influenza. 2020. Available at: < https://sbim.org.br/images/files/notas-tecnicas/ informe-tecnico-ms-campanha-influenza-2020-final. pdf > Access on: Aug. 10th 2020.

5. Monteles MS, Aragão FBA, Pereira JFS, Gomes FCS. Fatores de não adesão dos idosos à vacina contra influenza: uma revisão bibliográfica. Uningá Review. 2017; 30(3): 76-82. 
6. Gonçalves AR, Nogueira PC. Vacinação contra influenza para idosos: motivos da não adesão. Geriatr Gerontol Aging. 2013;7(2):142-45.

7. Campos EC, Sudan LCP, Mattos ED, Fidelis R. Fatores relacionados à vacinação contra a gripe em idosos: estudo transversal, Cambé, Paraná, Brasil. Cad. Saúde Pública, Rio de Janeiro, 2012; 28(5): 87888.

8. Oliveira LP, Lima ABS, Sá KVCS, Freitas DS, Aguiar MIF, Rabêlo PPC, et al. Perfil e situação vacinal de idosos em unidade de estratégia saúde da família. Rev Pesq Saúde, 2016; 17(1): 23-26.

9. Lino GG, Medeiros LB, Pinheiro JS. Motivos que levam os idosos à recusa das vacinas: uma revisão integrativa. Porto Velho. Final Paper [Undergraduate Course] -Centro Universitário São Lucas; 2018. Available at: < http://revista.saolucas.edu.br/index. php/resc/article/view/1119/pdf> Access on: Aug. 10th 2020.

10. Moura RF, Andrade FB, Duarte YAO, Lebrão ML, Antunes JLF. Factors associated with adherence to influenza vaccination among non-institutionalized elderly in São Paulo, Brazil. 2015; 31(10): 2157-68.

11. Souza MT, Silva MD, Carvalho R. Integrative review: what is it? How to do it?.. Einstein (São Paulo), São Paulo, 2010; 8(1): 102-06.

12. Ercole FF, Melo LS, Alcoforado CLG. Integrative Review versus Systematic Review In: Rev Min Enferm. Belo Horizonte, 2014; 18(1): 9-12.

13. Gil AC. Como elaborar projetos de pesquisa. 6 ed. São Paulo: Atlas; 2018.

14. Neves RG, Duro SMS, Tomasi E. Vacinação contra influenza em idosos de Pelotas-RS, 2014: um estudo transversal de base populacional. Epidemiol. Serv. Saúde, Brasília, 2016; 25(4): 755-66.

15. Neves NB, Guedes HM, Barbosa SP, Arêdes VTO. $A$ atuação da equipe de enfermagem na vacina do idoso institucionalizado: o caso de um município da região do vale do aço. Rev Min Enferm. Belo Horizonte, 2009; 13(3): 416-122.

16. Lima-Costa AMF. Fatores associados à vacinação contra gripe em idosos na região metropolitana de Belo Horizonte. Rev. Saúde Pública, São Paulo, 2008; 42(1): 100-07.

17. Francisco PMSB, Barros MBA, Cordeiro MRD. Vacinação contra influenza em idosos: prevalência, fatores associados e motivos da não-adesão em Campinas, São Paulo, Brasil. Cad. Saúde Pública, Rio de Janeiro, 2011; 27(3): 417-26

18. Geronutti DA, Molina AC, Lima SAM. Vacinação de idosos contra a influenza em um centro de saúde escola do interior do estado de São Paulo. Texto contexto - Enferm. Florianópolis, 2008:17(2): 336-41.

19. Francisco PMSB, Borim FSA, Neri AL. Vacinação contra influenza em idosos: dados do FIBRA, Campinas, São Paulo, Brasil. Ciênc. Saúde Coletiva, Rio de Janeiro, 2015; 20(12): 3775-86.

20.Silva,M.A.Análiseliteráriadosfatoresrelacionados à adesão da vacinação dos idosos brasileiros. São Paulo (Assis). Final Paper [Undergraduate Course] -IMESA; 2012. Available at: <https://cepein.femanet. com.br/BDigital/arqTccs/0911250104.pdf> Access on: Oct. 20th 2020.

21. Adamcheski JK, Wieczorkiecicz AM. Motivos que levam os idosos a não aceitarem uma vacina contra o vírus influenza. Saúde e Meio Ambient,: Rev Interdisciplin. 2012; 1(2): 117-29.

22. Gomes WR, Silva LA, Cruz AU, Almeida RC, Lima $\mathrm{RQ}$, Silva MC. Adesão dos idosos à vacinação contra gripe. Revista Enfermagem UFPE, Recife, 2013; 7(4): 1153-59.

23. Martins KM, Santos WL, Alvares ACM. A importância da imunização: revisão integrativa. Rev Inic Cient e Ext. 2018; 2(2): 96-01. 